\title{
The impact of the potential risks of the implementation of instruments for environmental area management on the development of urban settlement
}

\author{
J. Betáková ${ }^{1}$, M. Lorko ${ }^{1} \&$ J. Dvorský ${ }^{2}$ \\ ${ }^{I}$ Dubnica Institute of Technology, Slovakia \\ ${ }^{2}$ University of Žilina, Slovakia
}

\begin{abstract}
Complex permanently sustainable area development is not possible without the application of effective developmental policy. It is necessary to supply the optimization of environmental, social, economic and spatial aspects of the area development, of which cumulative and synergistic effects and impacts are seen especially in spatial planning. The main task of the spatial planning is to create the conditions for the application of environmental management aiming to use the potential of the area for permanently sustainable development too. Environmental management is market-oriented, developmental, aim-oriented process covering various sectional interests, plans and strategies with the aim to make an integrated concept of permanently sustainable area development. The aim of the research was the assessment of potential risks within the implementation of selected environmental management instruments and their impact on permanently sustainable development of urban settlement as well as to develop the recommendations in order to make this action more effective. We used an examination of environmental management individual instruments' effectiveness to supply permanent sustainable area development in this process. Based on the analysis, we concluded that environmental management individual instruments are clearly overlapped with pursued aims, principles as well as in procedural and institutional aspects. By analyzing and evaluating their effectiveness, we concluded that their functionality is not sufficient.

Keywords: ecology, environmental area management, urban settlement.
\end{abstract}




\section{Introduction}

Creating the concepts of permanently sustainable development of the area is a natural human response to the knowledge that any unregulated area development considering the limited amount of natural resources and population growth in the given area is not possible in the future. Environmental quality will increasingly depend on the economic development of given area. Therefore, sustainable development of residential structures won't be possible with the application of effective territorial development policy. Spatial planning as a traditional tool for managing the area development is adequately effective for several reasons now. Municipalities are in a difficult situation regarding gradual decay of financial interdependence on a systematic and regular finance flow from the state budget. Basically, the environment of the regulations and the limits substitutes the environment of stimulation tools' implementation. Currently, there are fears of commercial and political interests' preference to effective policy for permanently sustainable area development. We see the solution of this crisis situation problem in the consistent implementation of tools and methods of environmental area management in practice. It is an aimed development process covering the different sectorial interests and strategies in order to develop an integrated concept of permanently sustainable development of the area. It is a process of continuous managing the permanently sustainable development of human society in terms of spatial structures of the settlements.

\section{Urban settlement as a basic dimension of sustainable development policy implementation in Slovakia}

Urban settlements in Slovakia has developed not only as a result of spatial planning as well as the time depending continuity of events and functions of social, cultural, spatial and economic nature, which is a basic picture of culturalhistorical and social heritage, identity and continuity and also a challenge for sustainable development of the settlements. Sustainable development of the settlement is an image of the process of recognition, evaluation of resources and potentials of the area and sustainable approaches implementation in particular community, area, settlement, village and region. Generally, we could say that the existing residential structure of Slovakia and the rate of urbanization create the presumption for the use of the territorial potential of the country in the context of sustainable development of the country. Considering the urban settlement creates the basic unit of meaningful and responsible management with natural, cultural, historical, capital and human resources at the local level, therefore it is also the key to achieving sustainable development of the area., There are new processes characterized by an effort to restore natural relations in urbanized areas during the last period of development of Slovakia. The process of restoring the autonomy of municipalities and their settlement identity, as an important part of a democratic society, which is the basis of self-government was successfully implemented. The current situation in Slovakia can be characterized 
as a conflict between urban and rural environment, which is reflected in socio cultural, economic, political, but also environmental sphere. Deepening structural economic changes associated with technical and social infrastructure facilities, supported by specific geographic conditions contribute to the deepening the interregional differences and the positive formation of marginal and core regions. Marginalization is strongly manifested in social areas (the so-called problem regions) with low economic and social level and high unemployment rate, where the processes of social recession are spatially cumulated. Overall inequality is a consequence of the conditions of instability and unequal labour market supply and insufficient rural settlements activities. The situation requires a strategy of de-marginalisation of the society based on an individual approach to particular regions.

\section{The current problems of settlements development regarding sustainable development policy}

The dynamic character of political, economic and social changes in the early $21^{\text {st }}$ century are characterized by phenomena such as changes in the value orientation and migratory population movements that are closely related to the decrease in population of marginalized regions, as well as the loss of highly qualified people and the countryside agriculture decline. It is closely related to the decline in employment, production and management of marginalized regions. In addition, there are the negative effects of consumer society, an increased occurrence of socio-pathological phenomena, the loss of social control, population aging, environmental and traffic problems. On the contrary, this situation creates better conditions for the development of quality-oriented urban centres, leading to the development of urban lifestyles and stabilization of urban population. Among the limiting factors that hinder the sustainable development of urban settlements in Slovakia, we include mainly insufficient integrated practice in the context of sustainable development and long-term development planning of Slovakia as a whole. There is a lack of interconnectedness of development policies, lack of confrontation of spatial-planning activity with the real needs of citizens, unresolved property-legal relations to real estate, weak law enforceability, lengthy processes of property-legal inheritances settlement, real estate transfers, cadastral and building offices inflexibility, non-transparent system of disposable housing and monuments fund and the land fund register. This affects an inefficient decision-making in the field of public resources and taxes reallocation between the state and the self-government. There is a lack of the philosophy of public interest, understanding and creating the awareness of the sustainable principles acquisition, financing and maintenance of stateowned property and the private property. Without the systematic, synergic solution of these problems, it is unrealistic to expect the improvement of the situation of residential development and related activities. In terms of efficient and sustainable development of the area, the intrinsic quality of public administration (professionalism and competency of its employees) plays an important role. This state creates a platform for the application of environmental 
area management, which aims to use the development potential of the area in the context of sustainable development. The focus on long-term goals, continuity of individual processes, permanence and the bond between planning and implementation is characteristic for it.

\section{Environmental area management as an instrument of settlement system of sustainable development policy}

Environmental area management includes all activities associated with the management of properties and natural resources that are necessary to achieve sustainable area development. Instruments of environmental area management are not clearly defined, nor are they always used in the same way. Essentially, they can be divided into legislative, economic, organizational, regulatory, planning and communicational - focused on obtaining the information. While these tools are particularly formal means, methods constitute a way of using them and they can be divided into analysis, decision making, evaluating the options and setting the priorities for integrated environmental assessment of the impact on the environment and promoting environmental requirements for the given area. Implementation of the plans is necessary for sustainable area development in the environment of partnership, participation, subsidiarity and coordination of the interests of all participants in this process. The aim of the environmental area management is to protect and improve the environment by avoiding negative environmental impacts, there are implemented measures to protect the environment, as reflected in the relevant documentation (e.g. in ground plan) and legislative standards at different levels of governance, ultimately raise the environmental awareness of local inhabitants. Its tools such as EIA (Environmental Impact Assessment - EIA), environmental monitoring and environmental reporting are already commonly used even in Slovakia. Except EIA, majority of these tools is relatively new, so even terminology is not quite stable and the parallel tools development has led to different versions and models for one and the same tool.

\section{Spatial planning as a space-integrating tool of environmental area development}

The spatial planning solves systematically and comprehensively the spatial organization and functional use of the area, determines its principles, proposes substantive and temporal coordination of activities affecting the environment, ecological stability, cultural and historical values of the area, spatial development and landscape creation in accordance with the principles of sustainable development. Most laws in the field of protection of environment and nature are already in accordance with the ground plan, the approved activity or object in the process of area or construction management. Law on spatial planning in this context provides a platform for the integration of the process of creation and environmental protection and area-development processes. Individual activities, 
both of production and non-production nature, are reflected in different ways and overlap precisely in the area where you can keep track of their cumulative and synergic effects and impacts. Their impact is not possible to notice by summarizing data obtained by environmental assessment of individual projects because cumulative and synergic effects and impacts can be mapped precisely in their spatial projection, which reflect ground plans. We can say that ground plans create conditions for continued compliance of all activities in the given area, to maximize the utilization of its development potential, with special regard to environmental concerns, achieving ecological balance, the considerate use of natural resources, the preservation of natural, cultural and civilization values and to ensure sustainable area development. In order to achieve this goal, diagnostics of potential risks and a following comprehensive proposal is very important for the solution of potential risk situations in the context of sustainable development of the regional unit.

\section{Work methodology}

In order to achieve the objective assessment of the area and the effectiveness of environmental area management tools, there is also very important diagnostic of potential risks and following complex design of their solutions in accordance with sustainable area development. The subject of our research was the evaluation of the spatial implementation of environmental area management tools in the context of the evaluation of developmental potential and sustainable development of urban settlement. Individual instruments and their spatial impacts were examined in relation to legislative regulations in Slovakia, in order to integrate them into the ground plan of municipality and the system of spatial planning. Progressiveness of the approach was in the selection of appropriate planning and information mechanisms in order to create a methodological basis for mutual interaction of phases of each type of planning at the local level and spatial impacts of selected activities involved in management of developmental potential of settlement structure and the subsequent implementation - methodological recommendations. The basic framework for examining issues formed bonds between continuity of spatial development and the real using of spatial potential of settlement structure. In the context with spatial development of settlement formation, we clarified the role of environmental area management and its position within policy of permanently sustainable area development; we put the analysis of various managerial tools and the emergence of potential risk events and their spatial impacts. We evaluated the facts and assumptions of solutions aimed at creating the conditions for their implementations in practice within the system of spatial planning. We based on the assumption that an integrating factor for effective regional development compatible with the objectives of permanently sustainable development is spatial quality and the associated time-spatial continuity of planning at national, regional and local level. The principle of sustainability here creates a presumption and a fundamental starting point for assessing the developmental potential of the area in the context of generating emergence of 
potential crises and crisis phenomena in order to avoid negative impact on the development of settlements. In the research, we applied the comparative method in examining the various environmental management tools, analytic-synthetic method for making conclusions and method of induction and deduction. Basic research methodology was based on the principle of multi-level comprehensive analysis of selected activities and factors affecting the development of settlement.

We chose a comprehensive analysis based on the theory of system analysis and synthesis of theoretical and empirical process in the research is the basic method of our research. By systemic approach, we examined the determining factors of the current development of urban structures using the methods of a comprehensive assessment of the area, comparisons, economic analysis and statistical methods. In data processing and the experimental verification of theoretical knowledge we used qualitative and quantitative methods. Processing itself can be divided into three developmental stages:

- Analysis of theoretical knowledge and practical experiences compatible with the implementation of various tools of environmental area management and its spatial impact on the development of settlement formation.

- Analysis, quantification and the use of qualitative methods in the evaluation of synergistic and cumulative impacts in the context of sustainable development of settlement and system of planning mechanisms.

- Summary and formulation of conclusions for the practical application of advanced approaches to the assessment of developmental spatial potential of settlement formation.

\section{Theoretical-methodological resources}

We point out the principles and criteria of sustainable development in the selection and evaluation process of management tools. The villages were subjected to an analysis of the implementation of tools for environmental area management. The present methodology is processed and also applicable to other hierarchical levels of the settlements system. Reviewing the coincidence of environmental area management tools with the principles and criteria of sustainable development, we come out from a set of principles, which was accepted by the National Strategy for Sustainable Development of Slovakia. Their selection was subject to analysis creating the preconditions for sustainable development of the whole settlement. We chose the criteria with the focus to get the most objective picture of the application of those tools and their effectiveness in the implementation in practice. The evaluation is tied to economic tools of environmental area management, where are likely to have significant effects on the environment and in the field of housing, production, amenities and social infrastructure, sports and recreation, transportation, technical infrastructure, waste, landscaping, natural ingredients and elements. Our own assessment of the individual tools consists of the main formal and methodological steps: 
1. Overview of the different tools, their assessment of 5-point scale with regard to achieving sustainable development criteria (significant impact, positive impact, slightly positive impact, negative impact, the uncertainty of impact);

2. Expression of compatibility between different conceptual intentions with the assessment of 4-point scale (compatibility, partial compatibility, incompatibility, uncertainty);

3. Evaluation of conceptual intentions in terms of their negative, or positive effects with regard to:

- Wider context (international conventions, sectorial policies, plans and programs, transboundary impacts, planning documentation, plans and concepts already assessed under the Assessment Act on environmental impact;

- Impacts on population (health effects, cool factor, socio-economic conditions);

- Impacts on the natural environment (air, climate, water, soil, rocks, flora and fauna, protected elements of nature conservation, ecosystems);

- Impacts on the urban environment (cultural heritage, housing, social infrastructure, recreation, spas, transportation, technical infrastructure, manufacturing, waste management;

- Impacts on land (of of land, picture of landscape);

- Specific impacts;

- Overall evaluation of major anticipated impacts on the environment, the definition of cumulative impacts and proposal of effects mitigation measures (legal, land planning, technical, economic, environmental and other measures).

\section{Research evaluation and discussion}

During the evaluation, we examined not only the immediate satisfaction of human needs in the given area, but also change in the properties of the area and impact on the spatial system and its components in relation to the future functional use. Dominant part of this evaluation represents an assessment of the spatial quality. This process is objective; however, the actual determination of the value scale is subjective. In examining the dynamics of the spatial quality of settlement systems, we have verified in details the relationship of realization of individual activities of settlement to settlement system and its quality. In this analysis, we focused on self-assessment of spatial claims, and image of the area for a given activity, the image of the area, for example, their infrastructure etc., demands on the organization of the use of space, quality demands of space, the intensity of use of space, the spatial impact of activities, load of space, or degree of deformation of the original qualities of space. We found out that if the values of parameters reach a certain level, settlement system passes from stable state to a state of instability. After reaching that critical point, so called bifurcation point, it changes the structure of settlement systems, resulting in a new state of stability of the settlement systems. Synergy in this context seems a key phenomenon in 
the evolutionary movement of complex systems of settlement. Use of space and time in this sense becomes innovation that builds on the cultural and historical traditions. Watching these aspects was particularly important in the stage of changing methods of directive management of territorial and spatial development, unification of European structures and a shift to the use of methods of self-organization area. We found out that the conversion of the categorization of value of settlement systems is also very important, which constitute the base for quality of life in favour of individual rights of users of the area.

A new quality of the territory, which is objectively perceived as the resultant of interaction beyond the value properties of elements of space is in proportions, colours, position, compactness, structure, fracture elements flanking the space and in the properties area as a whole, such as its shape, size, colour, lighting, but also, for example, acoustic. Individual environmental limits of territorial development are basic determinants of community development. In general, the assumption that the limits and restrictions do not operate in isolation in the country, but synergistically, is confirmed. Determination of limiting and restrictive factors for a particular activity is based on the assessment of the functional relationship between the characteristics of area-creating elements of abiotic, biotic and socio-economic complex and the specific activity of social practice. In categorization of the area, we used the method according to Izakovičová [18], based on environmental limits coming from: the action of natural risks and hazards, the current land-use, needs of ensuring the stability and diversity of the country, needs of protection and rational use of natural resources, the protection needs of technical elements of landscape structure and elements of cultural heritage, the principles and laws of the functioning of the area and hygienic limits. We can conclude that spatial planning lacks the strategic objectification of economic and social objectives and qualified information not only for the application of the principles of permanently sustainable development of the area and their integration into the process of spatial planning documentation. Subsequently, in terms of spatial planning, there is an insufficient understanding of complex spatial planning activities in Slovakia, in particular the coordination function, all intents directly related to the development of urbanized and natural landscape. Directly related economic tools for environmental area management are also absent. The risk and crisis area management is insufficiently tied to these activities and there is completely undervalued function of preventing the potential socio-economic impact on the further development of the area. General principle says that prevention methods and solutions of the stress and crisis phenomena are proportionate to the level of knowledge and technical capabilities of the society. It is easier to predict the risks rather than let the risks surprise us. Assumption that the risk is present in any environment is the accompanying feature of any decision, whether good or bad. Whereas environmental crises in the territory never emerge by chance and without reason, it is always by some degree influenced by the environmental area management. Therefore, it is necessary to anticipate and prepare appropriate solutions to reduce the probability of crisis in particular area and to reduce the adverse impact resulting from potential crisis situations. 
Definition of the principles, conditions and rules for regulation the development of settlement systems is not possible without knowledge of the environment and processes in it, which by synergy effects affects the quality of the environment and solutions of possible conflict phenomena. The uniqueness of this approach lies in analytical view of the individual tools of spatial impact assessment, such as application, preventive tools and crisis area management in the context of permanently sustainable development of settlement formation.

\section{Conclusions and results of the work}

Environmental area management presents an integrated system of transfer of permanently sustainable society development ideas to its spatial projection. Integration of environmental, social and economic aspects of protection and creation of environment and other development trends of society and effective role of the various tools for environmental area management in this process require practical procedural framework for the implementation of the objectives of permanently sustainable development of the area. Individual tools of environmental area management provide adequate potential and rational basis for the process, in which synergistic and a long-term induced effects, in the form of structured or regulated processes, or through a process of changes in the overall preview or thinking, decision forms, to more effective planning and conceptual practices are defined. We can conclude that the only way to improve coordination and integration is to allow the tools of environmental area management being given to different levels of decision-making processes in the integration with other mechanisms of complex formation and planning of the development process.

Spatial planning as one of the dominant tools plays an important role in the transmission of sustainable development to the area. Practice shows the lack of effective integration and comprehensive assessment of ecological, social and economic issues in the settlement systems. It follows that the different tools of environmental area management overlap in their application form in order to achieve the objective, as well as its partial patterns and procedural and institutional aspects. The following problems dominantly act in the processes of their mutual integration:

- Ongoing analysis of the efficiency and effectiveness of implementation of the existing planning system and decision-making processes at national, regional, municipal level.

- Implementation of positive examples of integration of economic, social, environmental and institutional issues in land-use planning process across countries, regions and municipalities.

- Analysis of key aspects and elements that could define barriers to the integration of the individual tools within existing practice.

- Generate relevant linkages between individual tools of environmental area management, including their areal-spatial impacts and their projection in spatial planning practice. 
- System design of effective integration and implementation of individual tools of environmental area management in the processes of permanently sustainable development of the area.

Analysis of the implementation and evaluation of the effectiveness of tools of environmental area management draws attention to their insufficient functionality and efficiency. It has to do with the state of society as a whole as well as with individual systemic measures, what reflects their spatial impact. The aim of this paper is to contribute to the expansion of the theoretical base for understanding the synergy of planning processes and development of spatial quality of the area.

\section{References}

[1] Benčo, J., 2006: Ekonomika a manažment verejnej správy. Trenčín: FSEVTnUAD. 2006., ISBN 80-8075-119-6.

[2] Finka, M., 2001. Interdisciplinárne aspekty vývoja priestorovej kvality systémov osídlenia. Bratislava: Road, 2001, ISBN 80-88999-09- X.

[3] Hofreiter, L., 2002: Bezpečnostný manažment, Žilinská univerzita v Žiline, Fakulta špeciálneho inžinierstva, 2002 ISBN 80-7100-953-9.

[4] Ivančík, R., 2012: Bezpečnost' z pohl'adu ekonomickej teórie. In Politické vedy. [online]. Fakulta politických vied a medzinárodných vztahov UMB, Banská Bystrica Roč. 15, č. 3, 2012. ISSN 1338-5623, s. 100-124. Dostupné na internete: http://www.fpvmv.umb.sk/userfiles/ file/3_2012/IVANCIK.pdf.

[5] Mika, T., \& Kelíšek, A., 2010: Sociálna bezpečnost' z pohl'adu krízového manažmentu, In: Sociální, ekonomické a bezpečnostné otázky současnosti, Soukromní vysoká škola ekonomických studií, s.r.o., UNIPRESS s.r.o. Praha 2010, ISBN 978-80-86744-841.

[6] Mikolaj, J., 2001. Rizikový manažment, Žilina: RVS FŠI ŽU 2001, ISBN 80-88829-65-8

[7] Šikula, M. 2009: Dlhodobá vízia rozvoja slovenskej spoločnosti, A Long-Term Vision of the Slovak Society Development. Second (unchanged) edition. Bratislava: ÉÚ SAV 2009. Druhé, nezmenené vydanie. ISBN 978-80-7144-168-7.

[8] Šimák, L., 2006. Manažment rizík, Žilina: RVS FŠI ŽU 2006.

[9] Škvrnda, F., 2002: Vybratné socioekonomické aspekty bezpečnostných rizík In: Medzinárodní vztahy 2/ 2002, č. 2, s. 81-89. Praha, 2012.

[10] Finka, M., \& Petríková, D., a kol, 2004: Štúdia úlohy inštitúcií spolupracujúcich pri zabezpečovaní riadenia rozvoja územia s cielom vyvinút' vzdelávací program zameraný na dialóg medzi rôznymi inštitúciami vo výmene skúseností a znalostí. Bratislava: MVRR SR a Fakulta architektúry STU, 2004.

[11] Finka, M., \& Petríková D., 2000: Priestorový rozvoj a plánovanie v kontexte Európskej integrácie, Bratislava: ROAD, 2000, ISBN 8088999-02-2. 
[12] Finka, M., 2005: Competition and Cooperation-Classification of Instruments, In: Competition between Cities in Central Europe. Opportunities and Risks of Cooperation, Bratislava ROAD, 2005, ISBN 80-88999-27-8.

[13] Maier, K., \& Čtyroký J., 2000: Ekonomika územního rozvoje, Grada Publishing, 2000, ISBN 80-7169-644-7.

[14] Maier, K., 2002: Právní nástroje a reálne možnosti ovlivnit suburbanizaci, In: Suburbanizace, její sociální, ekonomické a ekologické důsledky, Praha, 2002, ISBN 80-901914-9-5.

[15] Maier, K., 2007: Princípy udržatelného rozvoje území, In: Principy a pravidla územního plánování, Ústav územního rozvoje, Brno: 2007, www.uur.cz.

[16] Mikolaj, J., a i., 2001: Krízový manažment ako spoločensko-vedný problém. Žilina : RVS FŠI ŽU, 2001.

[17] Sýkora, L., 2002: Suburbanizace a její sociální, ekonomické a ekologické důsledky. Praha, ISBN 80-901914-9-5.

[18] Izakovičová, Z., 2002: Environmentálne limity regionálního rozvoja, in: Acta Environmentalica Universitatis Comenianae (Bratislava) Supplement, Bratislava 2012, ISSN: 1335-0285. 